\title{
GROWTH AND SURVIVAL OF MULTIPURPOSE SPECIES; ASSESSING BILLION TREE AFFORESTATION PROJECT (BTAP), THE BONN CHALLENGE INITIATIVE
}

\author{
Ullah, I. ${ }^{1 *}-$ SAleEm, A. ${ }^{1}-$ Ansari, L. $^{1}-$ Ali, N. ${ }^{2}-$ AhMAD, N. ${ }^{1}-$ DAR, N. M. ${ }^{3}-$ DiN, N. U. ${ }^{3}$ \\ ${ }^{1}$ Department of Forestry and Range Management, University of Arid Agriculture, Rawalpindi, \\ Pakistan \\ (e-mail/phone: naveedahmad795@gmail.com/+92-332-903-3553 - N. Ahmad; +92-333-582- \\ 2202 - A. Saleem, +92-332-549-8460 - L. Ansari) \\ ${ }^{2}$ Forest Education Division, Pakistan Forest Institute, Peshawar, Pakistan \\ (e-mail/phone: foresternizar@gmail.com/+92-334-969-6981 - A. Nizar) \\ ${ }^{3}$ Institute of Geo-information and Earth Observation, University of Arid Agriculture, \\ Rawalpindi, Pakistan \\ (e-mail: mnadeemdar2454@gmail.com-M.N.Dar;noorsmk321@gmail.com-N.U.Din) \\ *Corresponding author \\ e-mail: irfanwazir577@gmail.com; phone: +92-335-928-0782
}

(Received $11^{\text {th }}$ Nov 2018; accepted $8^{\text {th }}$ Mar 2019)

\begin{abstract}
In context of Bonn Challenge commitment, Pakistan has implemented Billion Tree Afforestation Project (BTAP), the initiative of forest restoration and afforestation. The current research was a pilot one which evaluated the success of plantation and assessed growth performance and survival rate. A total of 115 sample plots ( 0.07 ha size) were laid out in 17 randomly selected sites extended over 1982 ha. Further, Sentinel-2 images were used to derive vegetation indices and regressed indices values with volume and survival percentage. Results showed that all plantation sites showed good performance in terms of survival rate (above 80\%). Highest growth performance was exhibited by Eucalyptus camaldulensis which mean height was1.297 (m) and the lowest was of Deodar 0.35 (m). Among Sentinel2 indices, Transformed Normalized Vegetation Index (TNDVI) has the highest value of $R^{2}$ of 0.425 whereas in case of survival percentage, Normalized Difference Vegetation Index (NDVI) has the highest value of $\mathrm{R}^{2}$ of 0.859 . Stepwise regression model showed that relationship between NDVI and volume was strongly significant compared to other indices. NDVI differencing of Landsat-8 2013 image and Sentinel22018 image showed that in NDVI range were increased from 0.68 to 0.85 , thus showed mosaic restoration and afforestation activities of BTAP.
\end{abstract}

Keywords: Sentinel-2, vegetation indices, forest restoration, Landsat-8, Eucalyptus camaldulensis

\section{Introduction}

Forests are among those ecosystems on earth that not only provide services to mankind but its biological, ecological and environmental services are manifold (Trumbore et al., 2015; Mori, 2017). Forests are of immense socioeconomic importance as a source of timber, pulpwood for paper making, fuel, and many non-wood products. Globally, forested region has been diminished for last 25 years from almost 31.6 to $30.6 \%$ from 1990 to 2015 respectively (FAO, 2015). Globally, about one to two billion hectares land degradation was identified by Global Partnership on Forest Landscape Restoration (Pistorius et al., 2017). Restoration of deforested areas and degraded areas can play significant role in environmental change mitigation (Guerra-De la Cruz and Galicia, 2017), conservation of biodiversity (Zwiener et al., 2017; Alves-Pinto et al., 2017) and yielding products and services that support local people's livelihoods (Ulian 
et al., 2017). Reducing Emission from deforestation and Forest Degradation (REDD+) is a globally accepted climate change mitigation initiative that primarily focused on emission reduction and ensuring forest conservation, sustainable forest management and enhancement of carbon stocks (Kelly, 2018; Hein et al., 2018; Bos et al., 2017). REDD+ can only be possible when afforestation, reforestation and plantation activities are supported and encouraged at local and regional scales (Kuemmerle et al., 2017).

The Bonn Challenge launched in 2011, is a global initiative of large-scale afforestation, reforestation and plantation programs to increase global forest stocks (De Jong et al., 2017). The Bonn Challenge not only further strengthens the present objectives of Global Partnership on Forest Landscape Restoration (GPFLR) but also provide opportunities for REDD+ and Convention on Biological Diversity (CBD) Aichi targets (Pistorius et al., 2017; Pistorius and Freiberg, 2014). Under the Bonn Challenge, different countries including Argentina, Colombia, Costa Rica, Ecuador, Ethiopia, Ghana, India, Madagascar, Mexico, Mozambique, Niger, Peru, Rwanda, Uganda, US Forest Service and Pakistan (Khyber Pukhtunkhwa) have committed large scale afforestation, plantations and restoration of forests (IUCN, 2018). The Bonn Challenge is committed to reforest and reclaim the degraded forests of about 150 million ha by 2020 and will approach to hit the target of 350 million ha till 2030 under New York Declaration on Forest Climate Summit (Pistorius and Freiberg, 2014; Climate Summit, 2014). The 150 million ha target will bring many benefits including about $84 \$$ billion per year to national economies and the restored forests will have capacity of $1 \mathrm{GtCO}_{2} \mathrm{e}$ per year sequestration (FAO, 2016). Among Bonn Challenge members, the US Forest Service has committed 15 million ha by 2020 , the highest compared to other members. US Forest Service has restored about 12.3 million ha of degraded forests or land (IUCN, 2018). Recently, nine countries (Tunisia, Turkey, Iran, Morocco, Lebanon, Algeria, Portugal, Spain and France) have endorsed Agadir Commitment to strengthen Forest and Landscape Restoration (FLR) mechanism so as arrive at Bonn Challenge Commitment (FAO FLRM, 2017). The Bonn Challenge also ensure implementation of many globally agreed commitments by climate change bodies such as United Nations Framework on Climate Change (UNFCCC), Convention on Biological Biodiversity (CBD), United Nation Convention to Combat Desertification (UNCCD) and United Nations conservation programs (Asner et al., 2017).

In the context of Bonn Challenge, the Khyber Pukhtunkhwa (KPK) province of Pakistan, situated in northern part of the country, has started massive tree plantation and restoration programs of degraded forests in June 2015. KPK government has committed 0.35 million ha of forests restoration and afforestation by 2020 . The potential benefits will include 120 million USD and $0.04 \mathrm{GtCO}_{2}$ sequestrations by 2020 (Laestadius et al., 2015). Pakistan is a forest deficit country with total land area of 88.43 million ha; with total forest area of 4.60 million forest and forest plantations which are equivalent to $5.23 \%$ of the total land area (Bukhari and Bajwa, 2012). About $40 \%$ of country forests are located in Khyber Pakhtunkhwa (KPK) province of Pakistan. The KPK province has diverse geo-ecological formation including many forest and vegetation types, ranging from at $250 \mathrm{~m}$ above mean sea level in the south to $7708 \mathrm{~m}$ high in the North. Around 20.25 of the area is forested with trees of fluctuating thickness and, and nine major vegetation type. Adding Alpine pastures to it makes almost one-third (28.98\%) of the province under forest ecosystem. Almost same proportion of land $(30.08 \%)$ is under agriculture (including orchards). Another $10.67 \%$ of the area is under rangelands (Go KP, 2016). Previously various forestry-based conservation and development projects 
have been completed in the past in Khyber Pukhtunkhwa, with the collaboration of provincial forest department, national government institution and international organizations. Some of the more famous projects include Malakand Social Forestry Project, Siran Forest Development Project and Kalam Integrated Development Project (Ahmed and Mahmood, 1998).

BTAP has been driven by present KP Government's dream of Green Growth which binds in the necessities to develop approaches towards sustainable forestry in Khyber Pukhtunkhwa. The project aimed to generate green jobs, gender equality and empowerment, also preserving Pakistan's forest resource while parallel addressing to the worldwide issue of environmental change (Go KP, 2015). The provincial forest department has initiated this project with primary targets to plan, support, design methodologies and launch sustainable forestry in KP through local communities' participation and to promote forestry-based employments. The project has been implemented in two phases; Phase-I in 2014-15 while Phase-II implementation was done in 2015-2017. The main targets of the project were establishment of departmental and private nurseries, closure within forests (fencing an area within forest for restoration purpose), plantation on communal and private lands, reclamation or rehabilitation of bad sites, reclamation of saline and waterlogged areas, roadside, canal side and railway side plantations and generating employment opportunities at local level (WWF, 2017). The project activities were monitored by third party, the World Wide Fund for Nature Pakistan (WWF-Pakistan). WWF-Pakistan has published phase wise monitoring reports and found that the project activities were successful (WWF, 2017, 2016).

Previously different researches reported growth and survival of different species as an indicator of plantation success (Leslie et al., 2018; Varghese et al., 2017; Yamada et al., 2016; Rawat et al., 2017; Edo et al., 2017). Pistorius et al. (2017) studied various opportunities, comparative cost and benefits of Forest Landscape Restoration (FLR) in Ethiopia under the Bonn Challenge and reported that FLR comprises mainly of five major components namely participatory forest management, degraded land restoration, afforestation on regional scale, woodland improvement and forest-based value chain investments. Rubilar et al. (2018) reported that productivity and sustainability in intensively managed plantations can be maintained through controlled genetic, environmental and silvicultural interactions. Binkley et al. (2017) examined growth and survival of Eucalyptus camaldulensis at different plantation sites along gradient at 36 locations. Sabastian et al. (2018) reported plantations success depends upon soil and slope as growth parameters such as diameter growth respond differently to these factors. Poersch et al. (2017) analyzed the growth of different Eucalyptus camaldulensis species and its relation with variables to identify differences in growth pattern, the study found the height growth was strongly affected by minimum temperature. Da Silva et al. (2010) estimated the carbon sequestration potential of road side planted Eucalyptus camaldulensis and considered the specie good for road side afforestation.

In large unreachable areas use of remote sensing is a cost-effective method of collecting data and provides an alternative source of data for extrapolating and estimating forest variables (Franklin et al., 2003). The data obtained can be quickly updated and compared with existing data, and the method can be easily incorporated with geographical information systems. These techniques have been effectively combined in many studies and factually noteworthy relationships between the spectral values (computed via Landsat satellite sensors) and field-estimated variables have been accounted for diameter at breast height, age and total height (Donoghue et al., 2004), 
volume (Poulain et al., 2010) and biomass (Ali et al., 2018). Secondly, Sentinel-2 is a state of the art sensor launched on 23 June 2015 by the European Space Agency (ESA). Contrasted with Landsat-8, Sentinel-2 imagery at high spatial resolution $(10 \mathrm{~m})$, this is expected to provide more accurate results (Rembold et al., 2015; Ali et al., 2018) and offering the capacity to detect small changes in vegetation. Sentinel-2 mission is a land observing star grouping of two indistinguishable satellites (Sentinel-2A and Sentinel2B) that convey high resolution optical imagery. The framework gives a worldwide inclusion of the Earth's territory surface and is described by its high temporal frequency of ten days, which makes it suitable for temporal vegetation assessment. Keeping the unprecedented success of BTAP it is essential to evaluate the different interventions of the project; in this context the current study was designed. The main objectives of the study was to assess the overall survival rate, growth rate and to evaluate and compare growth performance of different tree species raised under the BTAP in district Dir lower Khyber Pukhtunkhwa, Pakistan. Further, the aim of the present study was to look at the connection between an arrangement of field-estimated factors and spectral data obtained by the Landsat-8 OLI (Operational Land Imager) sensor and Senetinel-2 image.

\section{Materials and methods}

\section{Study area}

In North Western part of Khyber Pakhtunkhwa province, District Dir lower is located and is spread over an area of $1583 \mathrm{~km}^{2}$ (Fig. 1). The state lies most on the Panjkora River, which start in the mountainous area of Hindu Kush and join the Swat River close Chakdara. Apart from small areas in the south-west, Dir is a rocky, mountainous zone with peaks getting higher to $55,000 \mathrm{~m}(16,000 \mathrm{ft})$ in the north-east and $3,000 \mathrm{~m}$ $(9,800 \mathrm{ft})$ along the watersheds, with Swat toward the east and Afghanistan and chitral toward the west and north. The topography of the district Dir Lower is dominated my mountains and hills which are part of the ranges/branches of southern Hindukush with the highest peaks in the northern part of Dir. The significant valleys of District Dir Lower include: Maidan, Jandool, Timargara, Samarbagh and Asband. District dir lower has the population of 1,435,917 according to the 2017 census report. The considered population of Dir Lower was 1.0937 .091 in 2015 with same growth among the 1981 and 1998 census, i.e. $3.42 \%$ per annum (Population Census Organization, 2017).

\section{Forest inventory}

Stratified random sampling technique was adopted for the selection of sample plots within plantation sites. Sites were selected randomly from the list plantation provided by project management unit of Billion Tree Afforestation Project Office, Peshawar, Khyber Pukhtunkhwa. The total number of sampling plots was 115 in 17 different plantation sites keeping in view time and available resources. The detail of the sites, number and distribution of sample plots has been explained in Table 1. Sampling intensity is the sampled area divided by total area of plantation site and multiplied by 100. Sampling intensity has changed from site to site because of different area, species composition, accessibility and time limitation. The number of plots was calculated by dividing total area divide by plot size and multiplying it with sampling intensity. Field data collection was conduct from $25^{\text {th }}$ September 2017 to $13^{\text {th }}$ October 2017. Altogether, 115 circular plots every one of surface area $1000 \mathrm{~m}^{2}$ was set up. The plots were geo 
referenced in respect to a reference in respect to a reference frame work (WGS 84 Datum/UTM zone 43N). Sub meter GNSS receiver GPS was used in collecting plot data. Data was collected from 115 circular sample plots having $15 \mathrm{~m}$ radius while considering slope correction with the help of measuring tape and reference points. The number of sample plots varies with the area of plantation sites as per sampling. For the collection of data measuring tape is used along with Sunnto Clinometer. The total number of plants as per 10 feet by 10 feet spacing was 1076 plants in 0.07 ha plot size. Due to time shortage, we measure height and girth of $20 \% \pm 5$ plants randomly in each sample plot and note it in the prescribed inventory forms. Then next plot location was assigned keeping in view $200 \mathrm{~m}$ plot to plot distance and particular angular measurement. Measurements were conducted with great care as accuracy of assessment of growth performance depends upon these variables. As the plantation was raised in three phases as per BTAP activities, but my study only conclude the data of one phase which phase II measurement of species growth was assessed by measuring two attributes; girth and height and age of the plantation. Height and girth are considered best indicators of growth performance comparatively. The height of trees was found according to the formula in Equation 1 (WWF, 2016):

$$
H=(\tan \theta \times d)+a
$$

where:

$\mathrm{H}=$ Total height of tree in meter

$\theta=$ angle of tree to the top of the tree from observers' eyes

$\mathrm{d}=$ distance between the tree base and the observer in meter

$\mathrm{a}=$ Observer eye height in meter

Moreover, for survival rate pit density was counted as per departmental procedure and then it was up scaled to per hectare. The Pit density is the number of pits per unit area as explained in Equation 2 (WWF, 2016). It is an important indicator for assessing the success of a plantation program. Pit density was calculated for ten sampled sites with 10 feet $\times 10$ feet spacing which results in 1075 plants per hectares.

$$
\mathrm{N}=\frac{\mathrm{D} \div 3.28^{2}}{\mathrm{~A}}
$$

where:

$\mathrm{N}$ is the number of pits per hectare

$\mathrm{D}$ is the distance between two plants in feet

$\mathrm{A}$ is the area in square meters

Survival rate of plantation is the most important indicator for assessing the success or failure of plantation. The pit density and empty pits data was used to determine the survival rate of the plantation. Survival rate depends how much out of the total sowed seed or planted plants survived and will likely to become healthy plants in future (Eq. 3; WWF, 2016). The less number of empty pits the greater survival percentage for the particular site. Plot wise survival rates was up scaled to site wise survival rate by using pit density data and plantation areas.

$$
S_{p}=\frac{N_{e}}{N_{\mathrm{k}}} \times 100
$$


where

$\mathrm{S}_{\mathrm{p}}$ is the survival percentage

$\mathrm{N}_{\mathrm{e}}$ is the number of empty pits per hectare

$\mathrm{N}_{\mathrm{t}}$ is the number of total pits per hectare

All the enumerated plants were arranged by species name, number of trees per plot and site to know the species composition of all sampled plantation sites. Further, besides sampling planted in the pits, natural regeneration also plays out in the plantation areas. Natural regeneration was also observed during sampling in each site. Regeneration enumeration was divided into two categories, one having less than 9 inches height (not established) and other having more than 9 inches height (established). The site wise natural regeneration was also calculated as per collected data from sampled sites.

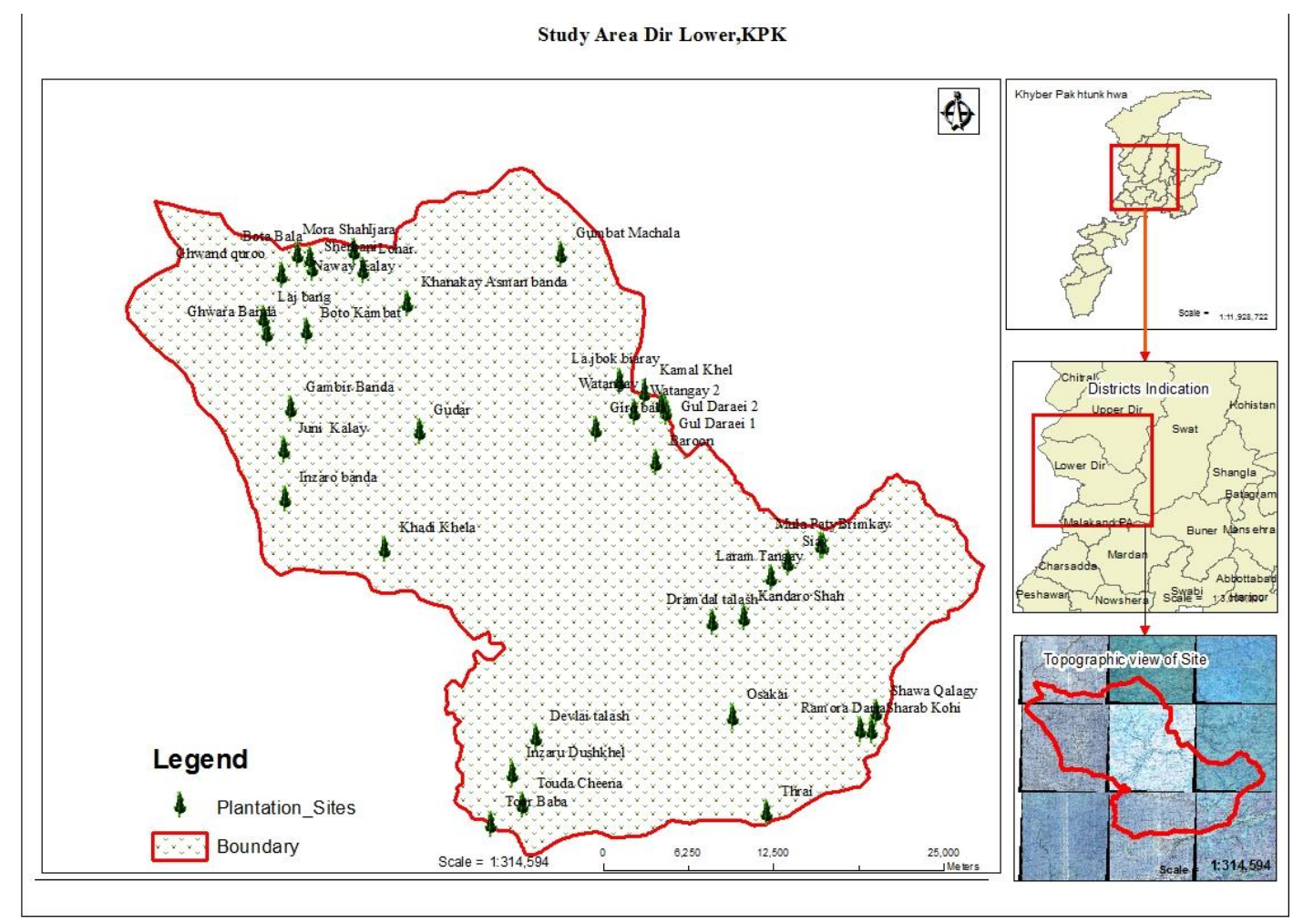

Figure 1. Map of study area

\section{Remote sensing}

The Landsat-8 Operational Land Imager (OLI) sensor image of in the study was acquired from the USGS Earth Explorer (http://earthexplorer.usgs.gov/). The image was acquired at the same time as the field sampling was carried out at the start of afforestation programs (January, 2014). The image was acquired as level L1T (i.e., they were geometrically rectified with ground control points). Landsat-8 image was carefully preprocessed by radiometric correction, topographic and dark object subtraction methods in ENVI 5.3. The Digital levels (DL) of each band were changed over to surface reflectance by perusing the model parameters and the geometrical attributes incorporated into the image metadata. Band 1 to 7 (B1, B2, B3, B4, B5, B6 and B7) of Landsat-8 OLI were used in the present study. The Sentinel-2 image was acquired from Copernicus Open 
Access Hub (https://scihub.copernicus.eu/). The Sentinel product was named as S2_MSI_Level-1C with processing Level-1C. Product bands ranged from 443 to $2190 \mathrm{~nm}$ with Band 2, 3, 4 and 8 in $10 \mathrm{~m}$, Band 5, 6, 7, 8A, 11 and 12 in $20 \mathrm{~m}$ and Band 1, 9 and 10 in $60 \mathrm{~m}$. Sentinel-2 image was corrected for atmospheric effects by applying the Sen2Cor version 2.2.1 software (Main-Knorn et al., 2015). The atmospheric correction transforms the Top-of Atmosphere level 1C product to Bottom-of Atmosphere atmospheric and terrain corrected product (level 2A) and its usability are described by Vuolo et al. (2016). A number of vegetation indexes and other derived parameters (Normalized difference vegetation index, NDVI; Modified soil adjusted vegetation index, MSAVI; Perpendicular Vegetation Index (PVI), Difference Vegetation Index (DVI), Transformed Normalized Difference Vegetation Index (TNDVI) were computed from the atmospherically and topographically corrected image bands and then included in the volume estimation models for evaluation as possible regress or variables.

\section{Statistical analysis}

Scatter plots were generated to analyze the relationship between volume $\left(\mathrm{m}^{3}\right)$ and individual indices (NDVI, MSAVI, PVI, DVI, TNDVI). Correlation and regression analysis (simple and stepwise models) were performed between volume $\left(\mathrm{m}^{3}\right)$ and spectral indices. Different models were established (linear, polynomial, power, logarithmic and exponential). Coefficient of determination $\left(\mathrm{R}^{2}\right)$ was calculated for each model with the level of significance $(\mathrm{P} \leq 0.05)$. As a result, model fulfilling the condition of highest value of $\mathrm{R}^{2}$, was selected for effective biomass estimation and generation of biomass map as well.

\section{Results}

\section{Pit density}

Pit density of all these plantation sites have been summarized in Table 1. The total area of sampled sites was 1980 ha and total numbers of pits were 2107789 with 1065 (Average) number of pits per hectare. The highest pit density was found at Lram Tngaeishah village with 1086 pits per hectare while Inzrudushkhl kmalkhel the lowest number of pits with 1022 pits per hectare. As per third party monitoring of BTAP, WWF reported that total plantation on areas in the study area was 1998.6 ha and total number of plants was 2150493 with 10 by 10 feet average plant to plants spacing (WWF, 2017). Table 1 also showed plot wise Information about survival rate of all sampled sites. Almost all of the sampled plantation sites showed better survival percentage i.e. above $70 \%$. As per plot level measurements, the highest survival percentage was observed at Shrbkohy Ramoradra with $91 \%$ whereas the lowest survival percentage was at Gambirghwara Banda area with $72 \%$. The comparatively high rate of survival is probably due to choice of species i.e. most of the plantations consist of Chir and Eucalyptus which shows very high survival rate in especially Eucalyptus shows high resistance for survival in harsh conditions and secondly due to intensive care provided by the department. Regarding site wise survival rates, the Shrbkohy Ramoradra showed the highest success rate with $91 \%$ survival percentage while Gambirghwara Banda showed the lowest success rate among the sampled sites with $72 \%$ survival. The BTAP monitoring (WWF, 2017) also reported that in northern circle of project area, the highest survival rate was found of Upper Dir 93.8\% in compared to 
other forest divisions while the rest were 90, 84.75, 82.97, 82.5, 81.5, 78, and 67 of Dirkohistan, Lower Dir, Swat, Buner, Kalam, Malakand and Alupri respectively. Yamada et al. (2016) conducted a study about the growth and survival of different tree species planted to renovate biodiversity at river side's and within Palm Plantations. Survival rates of 351 seedlings were above $90 \%$ during 3 years after planting. Rawat et al. (2017) evaluated multipurpose trees raised in three villages (Jaminikhal, Manjgaon, Hadiya) in India for biodiversity conservation and degraded lands restoration. After four years of plantation, survival rates were $96.6 \%, 90.3 \%$ and $71.1 \%$ for Jaminikhal, Manjgaon, Hadiya respectively. Poersch et al. (2017) reported survival rate of $96.43 \%$ for Eucalyptus camaldulenis in 12 months.

Table 1. Detail of plantation sites, total number of pits, empty pits and survival rate

\begin{tabular}{|c|c|c|c|c|c|c|c|c|c|}
\hline $\begin{array}{c}\text { Name of } \\
\text { plantation site }\end{array}$ & $\begin{array}{c}\text { Area } \\
\text { (ha) }\end{array}$ & $\begin{array}{c}\text { No of } \\
\text { sample } \\
\text { plots }\end{array}$ & $\begin{array}{c}\text { Average } \\
\text { pits per } \\
\text { ha }\end{array}$ & $\begin{array}{c}\text { Total no. } \\
\text { of pits }\end{array}$ & $\begin{array}{c}\text { Pits in } \\
\text { plots }\end{array}$ & $\begin{array}{c}\text { Empty } \\
\text { pits/plot }\end{array}$ & $\begin{array}{c}\text { Empty } \\
\text { (ha) }\end{array}$ & $\begin{array}{c}\text { Total } \\
\text { empty } \\
\text { pits }\end{array}$ & $\begin{array}{l}\text { Survival } \\
\text { rate (\%) }\end{array}$ \\
\hline $\begin{array}{c}\text { Oskaei touda } \\
\text { chena }\end{array}$ & 180 & 10 & 1054 & 189720 & 74 & 14 & 171 & 36000 & 81 \\
\hline Lram Tngaeishah & 73 & 5 & 1086 & 79278 & 76 & 9 & 129 & 9417 & 88 \\
\hline Sia Brimkpaty & 128 & 7 & 1034 & 132352 & 72 & 9 & 129 & 16512 & 88 \\
\hline TorbabaTharei & 83 & 5 & 1065 & 88395 & 74 & 13 & 186 & 15438 & 83 \\
\hline $\begin{array}{c}\text { Shrbkohy } \\
\text { Ramoradra }\end{array}$ & 44 & 3 & 1082 & 47608 & 75 & 9 & 129 & 5676 & 91 \\
\hline Juni kalay & 114 & 7 & 1067 & 121638 & 74 & 17 & 244 & 27816 & 77 \\
\hline $\begin{array}{l}\text { Laj Bang } \\
\text { Sherbani }\end{array}$ & 64 & 4 & 1056 & 67584 & 73 & 18 & 1314 & 84096 & 75 \\
\hline Lohar khadi shah & 88 & 5 & 1070 & 94160 & 75 & 12 & 172 & 15136 & 84 \\
\hline Botabala kambat & 197 & 11 & 1067 & 210199 & 74 & 15 & 215 & 42355 & 80 \\
\hline $\begin{array}{c}\text { Gambirghwara } \\
\text { Banda }\end{array}$ & 184 & 10 & 1072 & 197248 & 76 & 21 & 300 & 55200 & 72 \\
\hline $\begin{array}{c}\text { Ghwnd Quro } \\
\text { Ghudar }\end{array}$ & 110 & 6 & 1079 & 118690 & 76 & 13 & 186 & 20460 & 83 \\
\hline Bagh Maidan & 123 & 8 & 1081 & 132963 & 77 & 15 & 215 & 26445 & 81 \\
\hline $\begin{array}{c}\text { Baroon } \\
\text { sairtormang }\end{array}$ & 113 & 7 & 1075 & 121475 & 76 & 18 & 258 & 29154 & 76 \\
\hline Devilai talash & 195 & 11 & 1084 & 211380 & 76 & 15 & 215 & 41925 & 81 \\
\hline $\begin{array}{c}\text { Inzrudushkhl } \\
\text { kmalkhel }\end{array}$ & 111 & 6 & 1022 & 113442 & 71 & 9 & 129 & 14319 & 87 \\
\hline $\begin{array}{c}\text { Watangy } \\
\text { Gumbtmachla }\end{array}$ & 92 & 5 & 1058 & 97336 & 74 & 11 & 158 & 14536 & 85 \\
\hline Gul Daraei & 81 & 5 & 1041 & 84321 & 73 & 10 & 143 & 11583 & 86 \\
\hline TOTAL & 1980 & 115 & & 2107789 & & & & & \\
\hline
\end{tabular}

\section{Growth rate of different species}

The growth performance of different species is given in Table 2. Highest growth performance was exhibited Eucalyptus camaldulensis. Eucalyptus camaldulensis attained an average height of $1.29 \mathrm{~m}$. This high growth was due to very good conditions of the sites where Eucalyptus camaldulensis has been planted. On the other hand, the 
remaining species have the average height growth of, $1.12,0.96,0.85,0.79,0.76,0.58$, $0.54,0.45,0.44,0.44,0.36$ and 0.35 m of Robinia, Willow, Ailanthus, Shisham, Bakain, Chir, Persian Pine, Ippleipple, Walnut, Kail, Phulaei and deodar respectively. Data on growth performance of different tee species at different sites were also recorded to determine variation in growth at different sites. Leslie et al. (2018) studied growth functions for Eucalyptus camaldulensis, where Eucalyptus camaldulensis trees have attained height $(\mathrm{m})$ of $0.5,1.4,1.5$ and $2 \mathrm{~m}$ in 5, 14 and 29 respectively and overall mean height of $10.6 \mathrm{~m}$ in 5.5 years. Varghese et al. (2017) studied growth and wood properties of Eucalyptus camaldulensis raised from local seed sources and clones, the study reported that plants grow from local sources grow faster than clones. Poersch et al. (2017) evaluated monthly diameter and height growth of Eucalyptus camaldulensis during 12 months, diameter increment was recorded form $3.35 \mathrm{~cm}$ to $10.27 \mathrm{~cm}$ and height increment was recorded from 2.15 to $6.56 \mathrm{~cm}$.

Table 2. Detail of species utilized in plantation sites along with their age, DBH, height and volume $(n=115)$

\begin{tabular}{c|c|c|c|c}
\hline Species & Age (month) & $\begin{array}{c}\text { Dia }(\mathbf{c m}) \\
\text { mean }\end{array}$ & $\begin{array}{c}\text { Height }(\mathbf{m}) \\
\text { mean }\end{array}$ & Volume $\left(\mathbf{m}^{\mathbf{3}}\right)$ mean \\
\hline Pinus roxburghii & 17 & 4.15 & 0.59 & 0.0326 \\
Eucalyptus camaldulensis & 17 & 5.29 & 1.30 & 0.0540 \\
Robinia pseudoacacia & 17 & 4.18 & 1.12 & 0.0281 \\
Pinus gerardiana & 17 & 3.17 & 0.54 & 0.0024 \\
Cedrus deodara & 17 & 2.75 & 0.35 & 0.0008 \\
Acacia modesta & 17 & 2. & 0.37 & 0.0005 \\
Dalbergia sissoo & 17 & 4 & 0.79 & 0.0032 \\
Juglans regia & 17 & 2.21 & 0.45 & 0.0005 \\
Pinus wallichiana & 17 & 2.75 & 0.44 & 0.0005 \\
Salix tetrasperma & 17 & 3.2 & 0.96 & 0.0015 \\
Ailanthus altissima & 17 & 3.5 & 0.85 & 0.0018 \\
Leucaena leucocephela & 17 & 2.3 & 0.46 & 0.0002 \\
Melia azedarach & 17 & 3.2 & 0.76 & 0.0006 \\
\hline \multicolumn{2}{r}{}
\end{tabular}

\section{Relationship between volume $\left(\mathrm{m}^{3}\right)$ and Sentinel-2 spectral indices}

Different vegetation indices were assessed for their correlation with volume $\left(\mathrm{m}^{3}\right)$. Results obtained for different regression models for each index are shown in Figure 2. Among these indices TNDVI and NDVI has the highest value of $\mathrm{R}^{2}$ of 0.425 , followed by MSAVI with $\mathrm{R}^{2} 0.41$. Similarly, applying various regression models (linear, polynomial, power, logarithmic and exponential) the values of R2 change as per data behavior and model assumptions. Vafaei et al. (2018) reported that integration of Sentinel-2A with ALOS-2 PALSAR-2 can enhance vegetation estimation with greater accuracy. Among these two estimations of Sentinel-2A was more accurate. Adan (2017) reported that indices computed from Sentinel-2A have better potential to estimate biomass in contrast to vegetation indices of other sensors. 

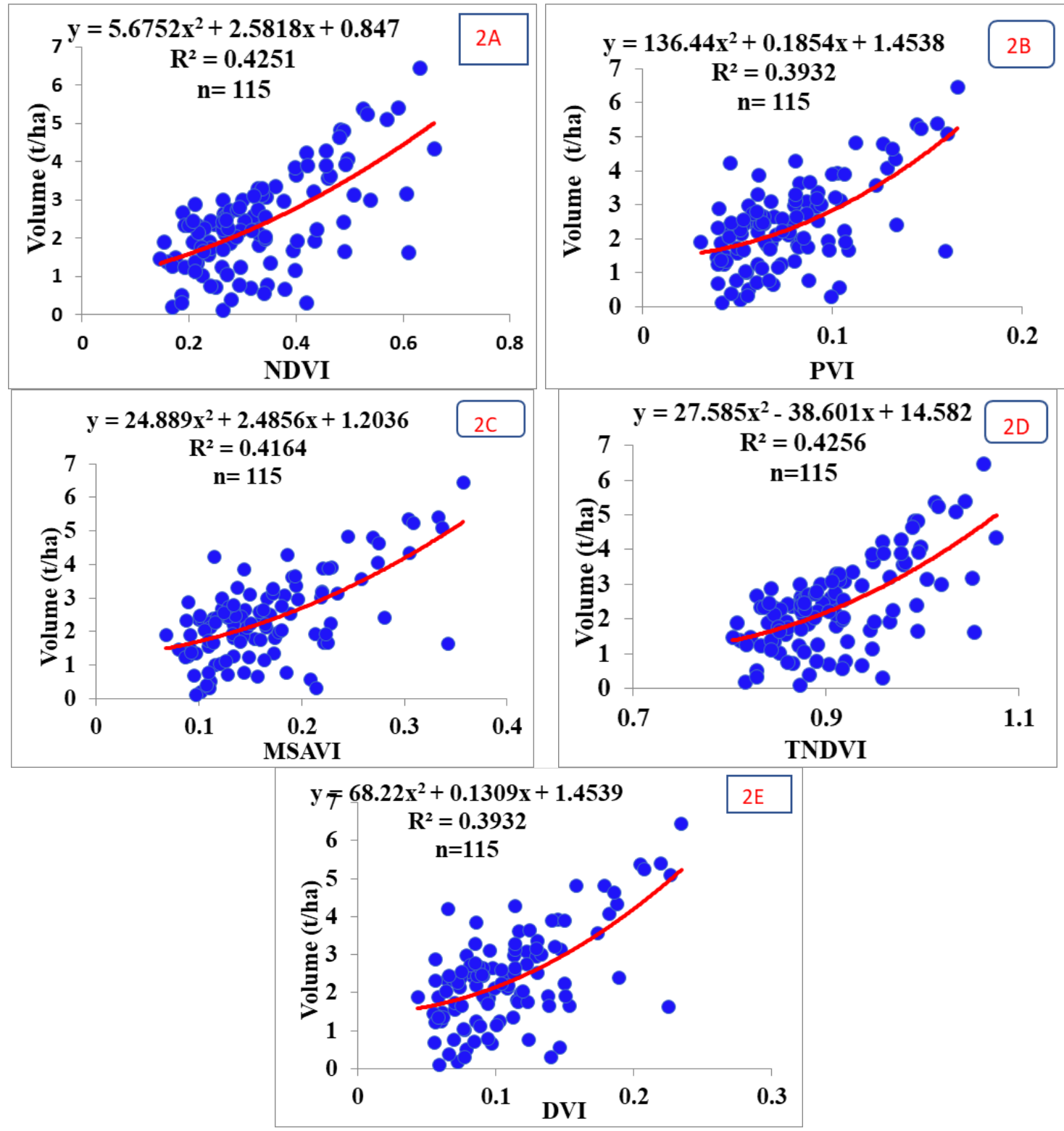

Figure 2. Scatterplots of spectral indices and volume (t/ha); where NDVI, PVI, MSAVI, TNDVI, $D V I$ were shown by Figure $2 a, b, c, d$ and e respectively

\section{Relationship between survival percentage and Sentinel-2 spectral indices}

Different vegetation indices were assessed for their correlation with survival percentage. Results obtained for different regression models for each index are shown in Figure 3. Among these indices NDVI has the highest value of $\mathrm{R}^{2}$ of 0.859 , followed by SAVI and DVI with 0.65 and 0.566 respectively. Similarly, applying various regression models (linear, polynomial, power, logarithmic and exponential) the values of R2 change as per data behavior and model assumptions.

\section{Stepwise regression model}

The stepwise Regression Model showed that NDVI was the best predictor for volume mapping at BTAP plantation sites. NDVI map was relatively the best to map 
biomass among other indices. Table 3 depicted that the relationship of NDVI and volume was strongly significant while the rest of the indices (TNDVI, MSAVI, DVI, PVI) was not significant under stepwise criteria (Probability-of-F-to-enter $<=.050$ and Probability-of-F-to-remove $>=.100$ ). The correlation matrix showed that NDVI has the highest correlation followed by TANDVI and MASVI with $\mathrm{R}^{2}$ values of $0.648,0.645$ and 0.637 respectively.

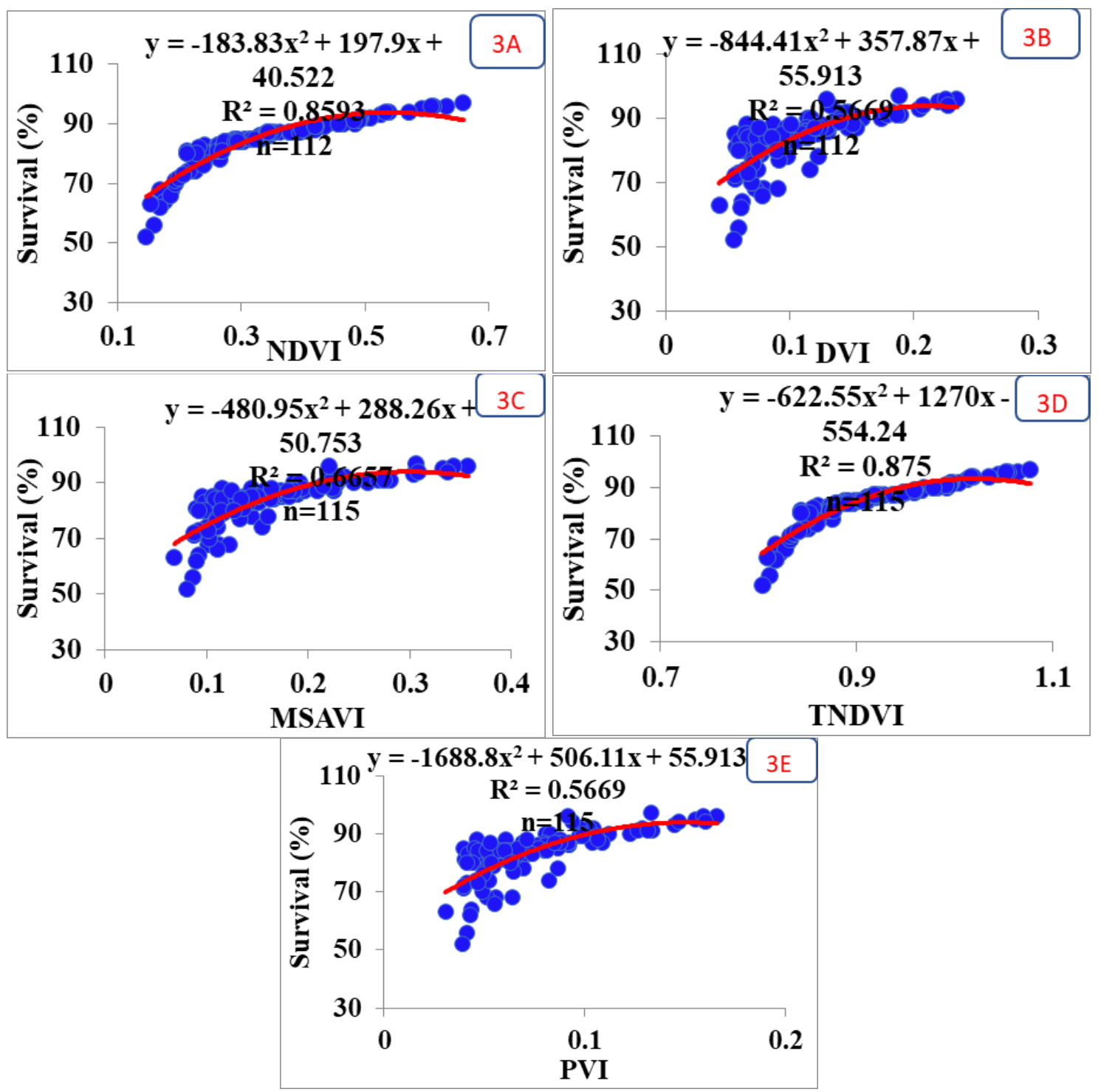

Figure 3. Scatterplots of spectral indices and survival rate (t/ha); Where NDVI, PVI, MSAVI, TNDVI, DVI were shown by Figures $2 a, b, 3 c, d$ and e, respectively

Whereas the overall $\mathrm{R}^{2}$ of model was 0.420 with standard error of 0.949 . Volume map of the plantation sites was produced using raster calculator in ArcGIS 10. Further, NDVI differencing showed that in NDVI range was from -0.65 to 0.68 in 2013 and the upper limit (value) was increased to 0.85 in 2018. Thus showed mosaic restoration and afforestation activities of BTAP. The lower sub-images of Figure 4 compared same plantation sites before and after the project activities which showed substantial increase 
in the vegetation cover from 2013 to 2018. Thus it can be concluded that BTAP activities were efficiently managed and supervised by the department. WWF (2016, 2017) and World Economic Forum (2017) reported that project activities were successful and meet its Bonn Challenge commitment by the end of 2017.

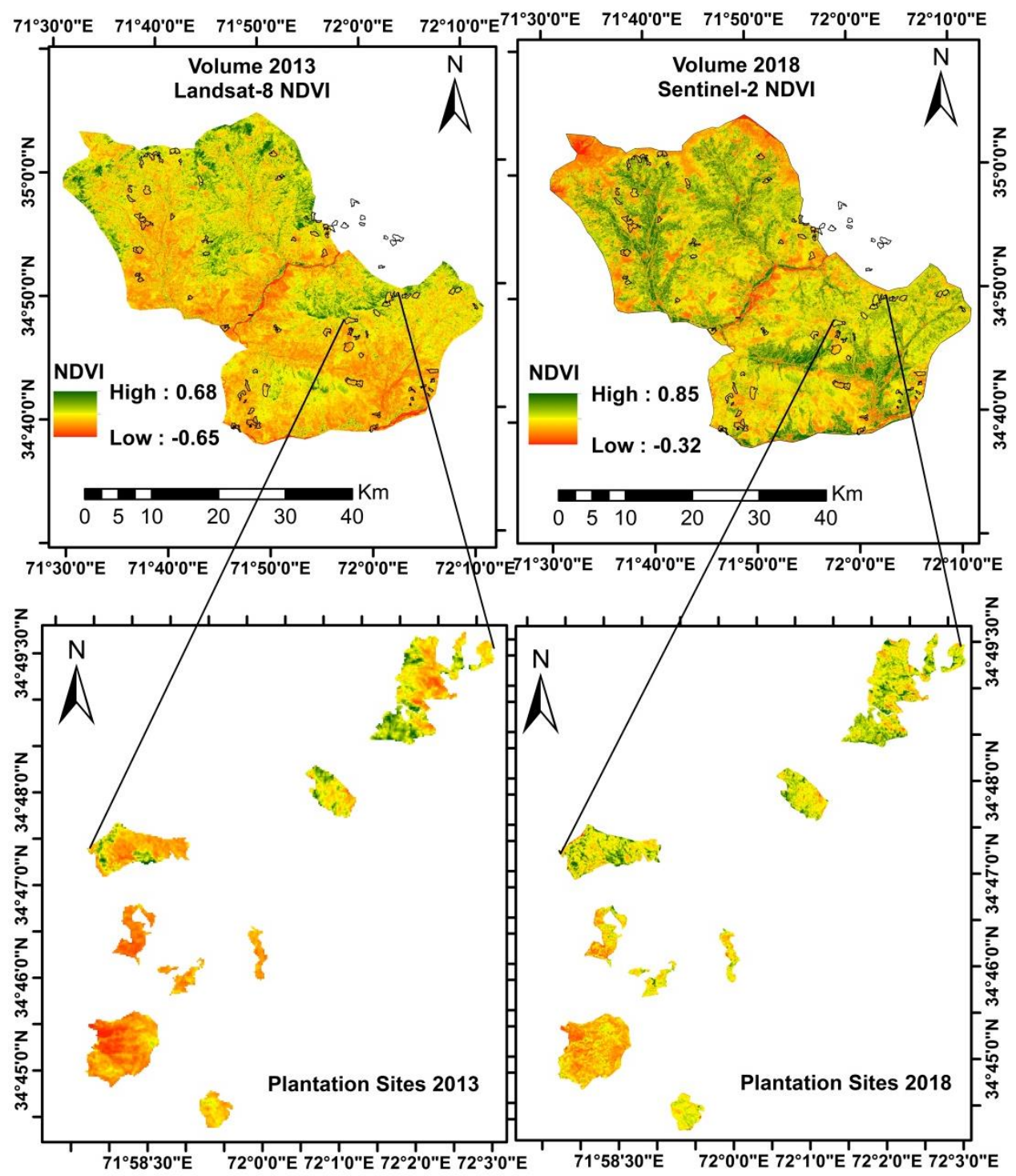

Figure 4. Comparison of plantation sites before and after plantation $(n=115)$

Table 3. Sentinel-2 stepwise regression $(P \leq 0.05, n=115)$

\begin{tabular}{c|c|c|c}
\hline \multicolumn{3}{|c}{ Sentinel-2 stepwise regression-variables entered/removed } \\
\hline $\begin{array}{c}\text { Variables } \\
\text { entered }\end{array}$ & $\begin{array}{c}\text { Variables } \\
\text { removed }\end{array}$ & Sig & Method/decision \\
\hline NDVI & & 0.000 & \\
& TNDVI & 0.296 & Stepwise (Criteria: Probability-of-F-to-enter $<=.050$, \\
& DVI & 0.151 & Probability-of-F-to-remove $>=.100)$. \\
& PVI & 0.151 & \\
\hline & MSAVI & 0.138 & \\
\hline
\end{tabular}




\begin{tabular}{c|c|c|c|c|c|c|c|c}
\hline \multicolumn{1}{c}{ Correlations } & Regression Summary \\
\hline & Biomass & TNDVI & DVI & PVI & MSAVI & NDVI & R & 0.648 \\
\hline Volume & 1.000 & & & & & & R square & 0.420 \\
\hline TNDVI & .645 & 1.000 & & & & & $\begin{array}{c}\text { Adjusted R } \\
\text { square }\end{array}$ & 0.415 \\
\hline DVI & .614 & .866 & 1.000 & & & & Std. error & 0.949 \\
\hline PVI & .614 & .866 & 0.993 & 1.000 & & & F-value & 81.052 \\
\hline MSAVI & .637 & .915 & .993 & .993 & 1.000 & & Sig & 0.000 \\
\hline NDVI & .648 & .999 & .869 & .869 & .918 & 1.000 & & \\
\hline \multicolumn{8}{c}{ Model equation } \\
\hline
\end{tabular}

\section{Conclusion}

The present research evaluated the BTAP success by survival rate and growth performance of major multipurpose species raised in 15 randomly selected sites of Dir lower Forest division. The overall survival rate and growth performance of plantations was found satisfactory. However, the share of Eucalyptus camaldulensis is more than other species which needs to be balanced in the future plantations. Pit density is found bit lesser than the required 10 feet by 10 feet spacing and in few sites it was $10 \times 11$ space i.e.1065 pits per hectare observed. Highest growth performance was exhibited Eucalyptus camaldulensis. Eucalyptus camaldulensis attained an average height of $1.29 \mathrm{~m}$. This high growth was due to very good conditions of the sites where Eucalyptus camaldulensis has been planted. On the other hand, the remaining species have the average height growth of, 1.12, 0.96, 0.85, 0.79, 0.76, 0.58, 0.54, 0.45, 0.44, 0.44, 0.36 and $0.35 \mathrm{~m}$ of Robinia, Willow, Ailanthus, Shisham, Bakain, Chir, Persian Pine, Ippleipple, Walnut, Kail, Phulaei and deodar respectively. Data on growth performance of different tee species at different sites were also recorded to determine variation in growth at different sites. Correlation between mean height $(\mathrm{m})$ and mean diameter $(\mathrm{cm})$ for all species was good and showed the overall data behavior shows good growth at present stage. If proper monitoring and management is continued for coming years, then these plantation will become fully established and contribute to successful implementation of Forest Landscape Restoration (FLR) under the Bonn Challenge commitment. To achieve future implementation and monitoring, based on the data collected during the field survey, personal observations of the researcher and interaction with staff of Forest Department and members of local community, some recommendation were suggested. There is a need to repeat such studies in the future to assess and monitor the survival rate and growth performance of plantations raised under BTAP. Due to shortage of time this study could not cover all the sites where plantations were raised. It is therefore advisable to conduct assessment of plantations in the sites not covered under the present study. It is also recommended to investigate the impacts of BTAP Plantations on ecological systems such as biodiversity, hydrological patterns and carbon sequestration after 5-10 years to ascertain the impacts on the ecosystem.

We also exhibit that using the free of charge Landsat- 8 and Sentinel-2 data and open source software is a possible alternative achieving assure results for BTAP plantation spatial and temporal monitoring. The study suggested that Sentinel-2A product has considerable potential to estimate biomass and map forest areas. The Sentinel-2A item 
has nearly substantial spatial inclusion and high goals to perform proficiently for estimation of biomass than other open source sensors information items.

\section{REFERENCES}

[1] Adan, M. S. (2017): Integrating Sentinel-2A derived indices and terrestrial laser scanner to estimate above ground biomass/carbon in Ayer Hitam tropical forest, Malaysia. Master of Science, University of Twente, The Netherlands.

[2] Ahmed, J., Mahmood, F. (1998): Changing Perspective on Forest Policy. Policy That Works for FORESTS and people. Pakistan Country Case Study. - IUCN, Islamabad.

[3] Ali, A., Ullah, S., Bushra, S., Ahmad, N., Ali, A. and Khan, M. A. (2018): Quantifying forest carbon stocks by integrating satellite images and forest inventory data. - Austrian Journal of Forest Science 135(2): 93-117.

[4] Alves-Pinto, H. N., Latawiec, A. E., Strassburg, B. B., Barros, F. S., Sansevero, J. B., Iribarrem, A., Crouzeilles, R., Lemgruber, L., Rangel, M. C., Silva, A. C. (2017): Reconciling rural development and ecological restoration: strategies and policy recommendations for the Brazilian Atlantic Forest. - Land Use Policy 60: 419-426.

[5] Asner, G. P., Martin, R. E., Tupayachi, R., Llactayo, W. (2017): Conservation assessment of the Peruvian Andes and Amazon based on mapped forest functional diversity. Biological Conservation 210: 80-88.

[6] Binkley, D., Campoe, O. C., Alvares, C., Carneiro, R. L., Cegatta, Í., Stape, J. L. (2017): The interactions of climate, spacing and genetics on clonal Eucalyptus plantations across Brazil and Uruguay. - Forest Ecology and Management 405: 271-283.

[7] Bos, A. B., Duchelle, A. E., Angelsen, A., Avitabile, V., De Sy, V., Herold, M., Joseph, S., De Sassi, C., Sills, E. O., Sunderlin, W. D., Wunder, S. (2017): Comparing methods for assessing the effectiveness of subnational REDD+ initiatives. - Environmental Research Letters 12(7): 074007.

[8] Bukhari, S. S. B., Bajwa, G. A. (2012): Development of National Response Strategy to Combat Impacts of Climate Change on Forest of Pakistan. - Pakistan Forest Institute, Peshawar.

[9] Da Silva, A. M., Braga Alves, C., Alves, S. H. (2010): Roadside vegetation: estimation and potential for carbon sequestration. - iForest-Biogeosciences and Forestry 3(5): 124.

[10] De Jong, W., Galloway, G., Katila, P., Pacheco, P. (2017): Forestry discourses and forest based development - an introduction to the Special Issue. - International Forestry Review 19(1): 1-9.

[11] Donoghue, D. N. M., Watt, P. J., Cox, N. J., Dunford, R. W., Wilson, J., Stables, S., Smith, S. (2004): An evaluation of the use of satellite data for monitoring early development of young Sitka spruce plantation forest growth. - Forestry 77(5): 383-396.

[12] Edo, G. Y., Gebremedihn, G. K., Woldsenbet, A. F., Guta, K. K. (2017): Growth performance of some multipurpose tree species around the homesteads in Gimbo district, Southwestern Ethiopia. - Agriculture, Forestry and Fisheries 6(1): 1-5. DOI: 10.11648/j.aff.20170601.11.

[13] FAO FLRM (2017): The Forest and Landscape Restoration Mechanism, Countries commit to support achievement of the Bonn Challenge and SDG15 in new Mediterranean dynamic. - http://www.fao.org/in-action/forest-landscape-restoration-mechanism/newsand-events/news-detail/en/c/878735/. Accessed on February 17, 2018.

[14] FAO (2015): Global Forest Resources Assessment. - FAO Forestry Research Paper 163, Rome. http://www.fao.org/3/a-i4808e.pdf. Accessed on February 20, 2018.

[15] FAO (2016): Food and Agricultural Organization and Bonn Challenge http://www.fao.org/fileadmin/user_upload/rap/Asia-

Pacific_Forestry_Week/doc/Stream_5/ST5_24Feb_SaintLaurent_FLR_IUCN.pdf.

Accessed on February 10, 2018. 
[16] Franklin, S. E., Hall, R. J., Smith, L., Gerylo, G. R. (2003): Discrimination of conifer height, age and crown closure classes using Landsat-5 TM imagery in the Canadian Northwest Territories. - International Journal of Remote Sensing 24(9): 1823-1834.

[17] Go, K. P. (2015): Revised PC-1 for Billion Trees Tsunami Afforestation Project in Khyber Pakhtunkhwa. - Department of Forestry, Environment \& Wildlife Govt. of Khyber Pakhtunkhwa. http://103.240.220.71/btt/repos/files/2015/12/PC1-Phase1.pdf. Accessed on February 13, 2018.

[18] Go, K. P. (2016): Khyber Pakhtunkhwa Biodiversity Strategy \& Action Plan http://www.devconsult.pk/wp-content/uploads/2016/06/KP-Biodiversity-Strategy-ActionPlan-2016-Final-Draft.pdf. Accessed on February 05, 2018.

[19] Galicia, L. (2017): Tropical and highland temperate forest plantations in Mexico: pathways for climate change mitigation and ecosystem services delivery. - Forests $8(12)$ : 489.

[20] Hein, J., Guarin, A., Frommé, E., Pauw, P. (2018): Deforestation and the Paris climate agreement: an assessment of REDD+ in the national climate action plans. - Forest Policy and Economics 90: 7-11.

[21] IUCN Forests (n.d.): The US Forest Service on tracing their Bonn Challenge Pledge. https://infoflr.org/news-media/us-forest-service-tracking-their-bonn-challenge-pledge.

Accessed on February 17, 2018.

[22] Kelly, A. C. (2018): Improving REDD+ (Reducing Emissions from Deforestation and Forest Degradation) Programs. - Doctoral Dissertation, University of Washington.

[23] Kuemmerle, T., Altrichter, M., Baldi, G., Cabido, M., Camino, M., Cuellar, E., Cuellar, R. L., Decarre, J., Díaz, S., Gasparri, I., Gavier-Pizarro, G. (2017): Forest conservation: remember Gran Chaco. - Science 355(6324): 465-465.

[24] Laestadius, L., Buckingham, K., Maginnis, S., Saint-Laurent, C. (2015): Before Bonn and beyond: the history and future of forest landscape restoration. - Unasylva 66(245): 11.

[25] Leslie, A. D., Mencuccini, M., Perks, M. P. (2018): Preliminary growth functions for Eucalyptus gunnii in the UK. - Biomass and Bioenergy 108: 464-469.

[26] Main-Knorn, M., Pflug, B., Debaecker, V., Louis, J. (2015): Calibration and validation plan for the L2a processor and products of the Sentinel-2 mission. - International Archives of the Photogrammetry, Remote Sensing \& Spatial Information Sciences 40: 1249-1255.

[27] Mori, A. S. (2017): Biodiversity and ecosystem services in forests: management and restoration founded on ecological theory. - Journal of Applied Ecology 54(1): 7-11.

[28] Pistorius, T., Freiberg, H. (2014): From target to implementation: perspectives for the international governance of forest landscape restoration. - Forests 5(3): 482-497.

[29] Pistorius, T., Carodenuto, S., Wathum, G. (2017): Implementing forest landscape restoration in Ethiopia. - Forests 8(3): 61.

[30] Poersch, N. L., FrançaFilho, L. R. T., Miguel, E. P., da Cruz, G. H. M., Francisquette, K. L., Cavalheiro, S. B. (2017): Influence of climate variables in the initial growth of Corymbiacitriodora and different species of eucalyptus. - Bioscience Journal 33(6).

[31] Population Census Report (2017): Lower DirBlockwise profile. http://www.pbscensus.gov.pk/sites/default/files/bwpsr/kp/LOWER\%20DIR_BLOCKWI SE.pdf.

[32] Poulain, M., Peña, M., Schmidt, A., Schmidt, H., Schulte, A. (2010): Relationships between forest variables and remote sensing data in a Nothofaguspumilio forest. Geocarto International 25(1): 25-43.

[33] Rawat, L. S., Maikhuri, R. K., Dhyani, D., Bahuguna, Y. M., Pharswan, D. S. (2017): Ecological restoration of village common degraded land through participatory approach for biodiversity conservation and socio-economic development in Indian Himalayan Region. - ActaEcologicaSinica 37(4): 240-252.

[34] Rembold, F., Leonardi, U., Ng, W. T., Gadain, H., Meroni, M., Atzberger, C. (2015): October. Mapping Areas Invaded by Prosopis Juliflora in Somaliland on Landsat 8 
Imagery. - In: Neale, C. M. U., Maltese, A. (eds.) Remote Sensing for Agriculture, Ecosystems, and Hydrology XVII. Vol. 9637: 963723. International Society for Optics and Photonics, Bellingham.

[35] Rubilar, R. A., Allen, H. L., Fox, T. R., Cook, R. L., Albaugh, T. J., Campoe, O. C. (2018): Advances in silviculture of intensively managed plantations. - Current Forestry Reports 4(1): 23-34.

[36] Sabastian, G. E., Kanowski, P., Williams, E., Roshetko, J. M. (2018): Tree diameter performance in relation to site quality in smallholder timber production systems in Gunungkidul, Indonesia. - Agroforestry Systems 92(1): 103-115.

[37] Trumbore, S., Brando, P., Hartmann, H. (2015): Forest health and global change. Science 349(6250): 814-818.

[38] Ulian, T., Sacandé, M., Hudson, A., Mattana, E. (2017): Conservation of indigenous plants to support community livelihoods: the MGU-Useful Plants Project. - Journal of Environmental Planning and Management 60(4): 668-683.

[39] UN Climate Summit (2014): New York Declaration on Forests. http://www.un.org/climatechange/summit/wp-content/uploads/sites/2/2014/07/New-

York-Declaration-on-Forest-\%E2\%80\%93-Action-Statement-and-Action-Plan.pdf.

Accessed on January 17, 2018.

[40] Vafaei, S., Soosani, J., Adeli, K., Fadaei, H., Naghavi, H., Pham, T., Tien Bui, D. (2018): Improving accuracy estimation of forest aboveground biomass based on incorporation of ALOS-2 PALSAR-2 and Sentinel-2A imagery and machine learning: a case study of the Hyrcanian forest area (Iran). - Remote Sensing 10(2): 172.

[41] Varghese, M., Harwood, C. E., Bush, D. J., Baltunis, B., Kamalakannan, R., Suraj, P. G., Hegde, D., Meder, R. (2017): Growth and wood properties of natural provenances, local seed sources and clones of Eucalyptus camaldulensis in southern India: implications for breeding and deployment. - New Forests 48(1): 67-82.

[42] Vuolo, F., Żółtak, M., Pipitone, C., Zappa, L., Wenng, H., Immitzer, M., Weiss, M., Baret, F., Atzberger, C. (2016): Data service platform for Sentinel-2 surface reflectance and value-added products: system use and examples. - Remote Sensing 8(11): 938.

[43] WEF-World Economic Forum (2017): Social Innovation. Environmental and Natural Resource Security. - https://www.weforum.org/agenda/2018/07/pakistan-s-billion-treetsunami-is-astonishing/. Accessed on October 30, 2018.

[44] WWF (2016): Third Party Monitoring of The Billion Trees Afforestation Project in Khyber Pakhtunkhwa Pakistan, World Wide Fund for Nature Pakistan. http://103.240.220.71/btt/third-party-monitoring-report-of-billion-trees-project-by-wwfpakistan/bttap-third-party-monitoring-report-final-version-9-final/. Accessed on February 05, 2018.

[45] WWF (2017): Third Party Monitoring of The Billion Trees Afforestation Project in Khyber Pakhtunkhwa Pakistan, World Wide Fund for Nature Pakistan. http://103.240.220.71/btt/repos/files/2018/02/THIRD-PARTY-MONITORING-OF-THEBTAP-PHASE-2-Part-2.pdf. Accessed on February 10, 2018.

[46] Yamada, T., Watanabe, K., Okuda, T., Sugimoto, T., Azlin, Y. N. (2016): Growth and survival of trees planted in an oil palm plantation: implications for restoration of biodiversity. - Journal of Tropical Forest Science 28(1): 97-105.

[47] Zwiener, V. P., Padial, A. A., Marques, M. C., Faleiro, F. V., Loyola, R., Peterson, A. T. (2017): Planning for conservation and restoration under climate and land use change in the Brazilian Atlantic Forest. - Diversity and Distributions 23(8): 955-966. 